\title{
Genetic, Biochemical, Nutritional and Antimicrobial Characteristics of Pomegranate (Punica granatum L.) Grown in Istria
}

\author{
Ana Miklavčič Višnjevec ${ }^{1}$, Ajda Ota², Mihaela Skrt², Bojan Butinar ${ }^{3}$, \\ Sonja Smole Možina ${ }^{2}$, Nina Gunde Cimerman ${ }^{2,4}$, Marijan Nečemer ${ }^{5}$, \\ Alenka Baruca Arbeiter ${ }^{1}$, Matjaž Hladnik', Marin Krapac ${ }^{6}$, Dean Ban ${ }^{6}$, \\ Milena Bučar-Miklavčič̌ ${ }^{3}$ Nataša Poklar Ulrih ${ }^{2}$ and Dunja Bandelj ${ }^{1 *}$ \\ ${ }^{1}$ Faculty of Mathematics, Natural Sciences and Information Technologies, University of Primorska, \\ Glagoljaška 8, SI-6000 Koper, Slovenia \\ ${ }^{2}$ Biotechnical Faculty, University of Ljubljana, Jamnikarjeva ulica 101, SI-1000 Ljubljana, Slovenia \\ ${ }^{3}$ Science and Research Centre Koper, Garibaldijeva 1, SI-6000 Koper, Slovenia \\ ${ }^{4}$ Centre of Excellence for Integrated Approaches in Chemistry and Biology of Proteins (CipKeBiP), \\ Jamova 39, SI-1000 Ljubljana, Slovenia \\ ${ }^{5}$ Jožef Stefan' Institute, Jamova cesta 39, SI-1000 Ljubljana, Slovenia \\ ${ }^{6}$ Institute of Agriculture and Tourism, Ul. Karla Huguesa 8, HR-52440 Poreč, Croatia
}

Received: May 12, 2016 Accepted: December 6, 2016

\begin{abstract}
Summary
This study characterises the genetic variability of local pomegranate (Punica granatum L.) germplasm from the Slovenian and Croatian areas of Istria. The bioactive components and antioxidant and antimicrobial properties of ethanol and water extracts of different parts of pomegranate fruit were also determined, along with their preliminary nutritional characterisation. Twenty-six different genotypes identified with microsatellite analysis indicate the great diversity of pomegranate in Istria. The pomegranate fruit ethanol extracts represent rich sources of phenolic compounds (mean value of the mass fraction in exocarp and mesocarp expressed as gallic acid is 23 and $16 \mathrm{mg} / \mathrm{g}$, respectively). The ethanol extracts of pomegranate exocarp and mesocarp showed the greatest antimicrobial activity against Candida albicans, Candida parapsilosis, Rhodotorula mucilaginosa, Exophiala dermatitidis and Staphylococcus aureus, and the same water extracts against S. aureus and Escherichia coli. To the best of our knowledge, this study represents the first report of the characterisation of pomegranate genetic resources from Istria at different levels, including the molecular, chemical, antimicrobial and nutritional properties.
\end{abstract}

Key words: Punica granatum L., bioactive components, genetic characteristics, antimicrobial and antifungal activity

\footnotetext{
*Corresponding author: Phone: +386 5611 7570; Fax: +386 5611 7571; E-mail: dunja.bandelj@upr.si

ORCiD IDs: 0000-0003-4259-6191 (Miklavčič Višnjevec), 0000-0001-6309-6669 (Ota), 0000-0002-9755-9673 (Skrt), 0000-0002-2018-632X (Butinar), 0000-0001-7949-8128 (Smole Možina), 0000-0002-9464-3263 (Grunde Cimerman), 0000-0003-0547-104X (Nečemer), 0000-00025535-3546 (Baruca Arbeiter), 0000-0002-7955-2873 (Hladnik), 0000-0003-0741-388X (Krapac), 0000-0002-7335-637X (Ban), 0000-00024929-2249 (Bučar-Miklavčič), 0000-0002-2731-9973 (Poklar Urlih), 0000-0001-6927-9642 (Bandelj)
} 


\section{Introduction}

Horticultural plants are very important for human diet as sources of vitamins, minerals and dietary fibre. They have also become a significant part of human life due to their medicinal and environmental uses as well as their aesthetic and economic values. The stem, leaves, flowers, roots, and vegetable and fruit crops have the highest potential of utilisation (1-4). Pomegranate (Punica granatum L.) belongs to the Lythraceae family (5). The $P u$ nica genus includes only two species: $P$. granatum L. and $P$. protopunica Balf, with the former believed to be autochthonous to an area between Iran and the Himalayas in northern India $(6,7)$. Due to its good adaptation to a wide range of climate and soil conditions, pomegranate is now grown in many different geographical regions including the Mediterranean basin, Asia and California, USA (8). The pomegranate fruit is commonly consumed fresh and it is also used for production of juice, syrup, jam and wine (6).

Pomegranate fruit represents a rich source of bioactive components and minerals (9). These have been reported in different parts of the fruit, such as the exocarp, seeds and arils (10). Moreover, other compounds in the fruit can have protective influence on human health, such as punicic acid, a conjugated fatty acid in pomegranate seed oil.

The functional properties of this fruit and the need for breeding programs for pomegranate have encouraged genetic investigations. Although pomegranate is considered as an underused and minor fruit species $(11,12)$, efforts to develop new and highly informative microsatellite molecular markers have been developed in $P$. granatum $(7,13-17)$. Their applicability to $P$. granatum DNA genotyping procedures and diversity studies has been demonstrated in Iran $(15,16)$, Tunisia $(14,17)$ and Turkey (13).

In the northern Adriatic region, large pomegranate orchards are rare, although individual trees are frequently planted in home and market gardens together with olives, figs, and other Mediterranean plants. Nevertheless, the economic potential and functional properties of this fruit suggest the larger cultivation of pomegranate. For successful promotion of the cultivation of local ecotypes that are already present in the region of Istria, investigation into the $P$. granatum genetic resources and the identification of the most promising ecotypes is necessary. To the best of our knowledge, this study represents the first report on the characterisation of $P$. granatum genetic resources from Istria at the molecular, chemical, antimicrobial and nutritional levels.

The aim of the present study was to characterise the genetic variability of the local $P$. granatum germplasm from the Slovenian and Croatian areas of Istria. Furthermore, we investigated the content of important phenolic compounds and their antioxidant properties in ethanol and water extracts of different parts of pomegranate fruit, along with their antimicrobial properties. In addition, preliminary characterisation of the nutritional properties of different parts of $P$. granatum fruit was performed. It is important to note that the genetic, antimicrobial and chemical properties were assessed for the same samples.

\section{Materials and Methods}

\section{Plant material and collection sites}

Thirty-five pomegranate (Punica granatum) samples were used for the genetic characterisation. These included varieties with known provenance, as well as local accessions and potential wild forms from Slovenian and Croatian areas of Istria (Table 1), a peninsula on the northern coast of the Adriatic Sea. The plant materials of this regional pomegranate germplasm were collected in the field, mostly from family gardens and orchards, along with the $P$. granatum varieties provided by the nursery Skink Ltd (Rovinj, Croatia) for molecular analysis. Chemical analysis was performed on eight of the selected samples, coded Pg1, Pg5, Pg6, Pg7, Pg8, Pg9, Pg10 and Pg12 (Table 1).

The climate in the coastal part of Istrian peninsula is Mediterranean (Cs according to Köppen classification), with mild winters and dry and warm summers, and an average of $2400 \mathrm{~h}$ of sunshine per year (18). The average monthly temperatures range from a minimum of $6{ }^{\circ} \mathrm{C}$ in January, to a maximum of $26^{\circ} \mathrm{C}$ in July. The average minimum monthly rainfall is in July $(40.1 \mathrm{~mm})$ and the average maximum monthly rainfall is in November $(101.8 \mathrm{~mm})$. The terrain in Istria is mostly a limestone plateau, much of which lacks water due to its karst topography.

The sampled $P$. granatum trees and shrubs were extensively cultivated using no special agronomic technologies (e.g. irrigation, fertilisation, plant protection). The pomegranate fruits were harvested in the beginning of November 2014, as part of the normal ripening period for pomegranate in different parts of Istria (Table 1: Baredi, Izola, Koper, Kampolin, Marasi, Rovinj, Rabac and Seča). The fruits were harvested randomly from each of the four orientations of the plants, and were immediately taken to the laboratory for analysis. For chemical analysis only healthy, ripe fruits were included. Based on these exclusion factors, 2 to 13 fruits were included in each single sample.

The pomegranate seeds and arils were separated from the exocarp and mesocarp. Before determination of the phenolic compounds and the antioxidant and antimicrobial properties, different parts of the pomegranate (exocarp, mesocarp and squeezed juice from arils) were lyophilised, with the remaining deposits crushed to form powders. The water and $70 \%$ ethanol extracts from these exocarp, mesocarp and aril samples were prepared by extraction of $5 \mathrm{~g}$ of lyophilised powdered mesocarp in 40 $\mathrm{mL}$ of solvent (water and $70 \%$ ethanol) for $4 \mathrm{~h}$. These extracts were then centrifuged at $10000 \times g$ (model Rotanda 460R; Hettich, Tuttlingen, Germany), dried under rotary evaporation (model HT-4 Series II; Genevac Ltd, Ipswich, UK) and lyophilised (model Alpha 1-2 LD plus; Christ, Osterode, Germany). These deposits from the extracts were kept at $-20^{\circ} \mathrm{C}$ until further analysis.

\section{Genetic analysis}

\section{DNA extraction and genotyping}

As pomegranate contains high amounts of polysaccharides and polyphenolic compounds (19), the total DNA was extracted from leaf tissue according to a slight- 
Table 1. Pomegranate (Punica granatum L.) accessions used in this study

\begin{tabular}{|c|c|c|c|c|}
\hline $\begin{array}{l}\text { Collection } \\
\text { site, } \\
\text { country }\end{array}$ & Code & $\begin{array}{l}\text { Variety name/ } \\
\text { local accession } \\
\text { name }\end{array}$ & $\begin{array}{l}\text { Latitude } \\
(\mathrm{N})\end{array}$ & $\begin{array}{l}\text { Longitude } \\
\text { (E) }\end{array}$ \\
\hline $\begin{array}{l}\text { Baredi, } \\
\text { Slovenia }\end{array}$ & $\operatorname{Pg} 1^{1}$ & Unknown & $45^{\circ} 30^{\prime} 53^{\prime \prime}$ & $13^{\circ} 40^{\prime} 59.4^{\prime \prime}$ \\
\hline \multirow{4}{*}{$\begin{array}{l}\text { Izola, } \\
\text { Slovenia }\end{array}$} & $\operatorname{Pg} 2$ & Unknown & $45^{\circ} 32^{\prime} 23.3^{\prime \prime}$ & $13^{\circ} 41^{\prime} 19.8^{\prime \prime}$ \\
\hline & Pg3 & Unknown & $45^{\circ} 32^{\prime} 23.6^{\prime \prime}$ & $13^{\circ} 41^{\prime} 19.3^{\prime \prime}$ \\
\hline & $\operatorname{Pg} 4$ & Unknown & $45^{\circ} 32^{\prime} 23.4^{\prime \prime}$ & $13^{\circ} 41^{\prime} 19.2^{\prime \prime}$ \\
\hline & $\operatorname{Pg} 5^{1}$ & Unknown & $45^{\circ} 32^{\prime} 23.3^{\prime \prime}$ & $13^{\circ} 41^{\prime} 19.5^{\prime \prime}$ \\
\hline $\begin{array}{l}\text { Koper, } \\
\text { Slovenia }\end{array}$ & $\operatorname{Pg} 6^{1}$ & Unknown & $45^{\circ} 32^{\prime} 5.5^{\prime \prime}$ & $13^{\circ} 41^{\prime} 56.6^{\prime \prime}$ \\
\hline \multirow{2}{*}{$\begin{array}{l}\text { Kampolin, } \\
\text { Slovenia }\end{array}$} & $\operatorname{Pg} 7^{1}$ & Unknown & $45^{\circ} 30^{\prime} 43.9^{\prime \prime}$ & $13^{\circ} 36^{\prime} 4.9^{\prime \prime}$ \\
\hline & $\operatorname{Pg} 8^{1}$ & Unknown & $45^{\circ} 30^{\prime} 43.9^{\prime \prime}$ & $13^{\circ} 36^{\prime} 5.2^{\prime \prime}$ \\
\hline \multirow{4}{*}{$\begin{array}{l}\text { Marasi, } \\
\text { Croatia }\end{array}$} & $\operatorname{Pg} 9^{1}$ & Unknown & $45^{\circ} 9^{\prime} 29^{\prime \prime}$ & $13^{\circ} 42^{\prime} 29.8^{\prime \prime}$ \\
\hline & $\operatorname{Pg} 10^{1}$ & Unknown & $45^{\circ} 9^{\prime} 29^{\prime \prime}$ & $13^{\circ} 42^{\prime} 29.9^{\prime \prime}$ \\
\hline & $\operatorname{Pg} 11$ & Unknown & $45^{\circ} 9^{\prime} 29.5^{\prime \prime}$ & $13^{\circ} 42^{\prime} 32^{\prime \prime}$ \\
\hline & $\operatorname{Pg} 12^{1}$ & Unknown & $45^{\circ} 9^{\prime} 28.7^{\prime \prime}$ & $13^{\circ} 42^{\prime} 33.1^{\prime \prime}$ \\
\hline \multirow{13}{*}{$\begin{array}{l}\text { Skink Ltd, } \\
\text { Rovinj, } \\
\text { Croatia }\end{array}$} & $\operatorname{Pg} 13$ & $\mathrm{Nar}^{\prime 2}$ & $45^{\circ} 6^{\prime} 41.2^{\prime \prime}$ & $13^{\circ} 38^{\prime} 12.7^{\prime \prime}$ \\
\hline & Pg14 & 'Irački ljutunac' ${ }^{2}$ & $45^{\circ} 6^{\prime} 41.2^{\prime \prime}$ & $13^{\circ} 38^{\prime} 12.7^{\prime \prime}$ \\
\hline & Pg15 & 'Barski sladun’’ & $45^{\circ} 6^{\prime} 41.2^{\prime \prime}$ & $13^{\circ} 38^{\prime} 12.7^{\prime \prime}$ \\
\hline & $\operatorname{Pg} 16$ & $\begin{array}{l}\text { 'Barski žuto- } \\
\text { narančaste kore' }\end{array}$ & $45^{\circ} 6^{\prime} 41.2^{\prime \prime}$ & $13^{\circ} 38^{\prime} 12.7^{\prime \prime}$ \\
\hline & Pg17 & 'Rumanjaš slatki' ${ }^{2}$ & $45^{\circ} 6^{\prime} 41.2^{\prime \prime}$ & $13^{\circ} 38^{\prime} 12.7^{\prime \prime}$ \\
\hline & Pg18 & 'Slatki rani'² & $45^{\circ} 6^{\prime} 41.2^{\prime \prime}$ & $13^{\circ} 38^{\prime} 12.7^{\prime \prime}$ \\
\hline & $\operatorname{Pg} 19$ & $\begin{array}{l}\text { 'Dente di } \\
\text { Cavallo' }^{3}\end{array}$ & $45^{\circ} 6^{\prime} 41.2^{\prime \prime}$ & $13^{\circ} 38^{\prime} 12.7^{\prime \prime}$ \\
\hline & Pg20 & 'Medun'² & $45^{\circ} 6^{\prime} 41.2^{\prime \prime}$ & $13^{\circ} 38^{\prime} 12.7^{\prime \prime}$ \\
\hline & $\operatorname{Pg} 21$ & $\begin{array}{l}\text { ‘Modraš divlji } \\
\text { šipek' }\end{array}$ & $45^{\circ} 6^{\prime} 41.2^{\prime \prime}$ & $13^{\circ} 38^{\prime} 12.7^{\prime \prime}$ \\
\hline & $\operatorname{Pg} 22$ & 'Glavaš'” & $45^{\circ} 6^{\prime} 41.2^{\prime \prime}$ & $13^{\circ} 38^{\prime} 12.7^{\prime \prime}$ \\
\hline & Pg23 & 'Valenciana' ${ }^{3}$ & $45^{\circ} 6^{\prime} 41.2^{\prime \prime}$ & $13^{\circ} 38^{\prime} 12.7^{\prime \prime}$ \\
\hline & $\operatorname{Pg} 24$ & 'Wonderful' ${ }^{3}$ & $45^{\circ} 6^{\prime} 41.2^{\prime \prime}$ & $13^{\circ} 38^{\prime} 12.7^{\prime \prime}$ \\
\hline & Pg25 & 'Mollar de Elche' ${ }^{3}$ & $45^{\circ} 6^{\prime} 41.2^{\prime \prime}$ & $13^{\circ} 38^{\prime} 12.7^{\prime \prime}$ \\
\hline \multirow{5}{*}{$\begin{array}{l}\text { Rabac, } \\
\text { Croatia }\end{array}$} & $\operatorname{Pg} 26$ & Unknown & $45^{\circ} 4^{\prime} 37.8^{\prime \prime}$ & $13^{\circ} 40^{\prime} 44.5^{\prime \prime}$ \\
\hline & Pg27 & Unknown & $45^{\circ} 4^{\prime} 37.8^{\prime \prime}$ & $13^{\circ} 40^{\prime} 44.7^{\prime \prime}$ \\
\hline & $\operatorname{Pg} 28$ & Unknown & $45^{\circ} 4^{\prime} 37.9^{\prime \prime}$ & $13^{\circ} 40^{\prime} 44.6^{\prime \prime}$ \\
\hline & Pg29 & Unknown & $45^{\circ} 4^{\prime} 37.6^{\prime \prime}$ & $13^{\circ} 40^{\prime} 42.9^{\prime \prime}$ \\
\hline & Pg30 & Wild & $45^{\circ} 5^{\prime} 11.5^{\prime \prime}$ & $14^{\circ} 9^{\prime} 28.7^{\prime \prime}$ \\
\hline \multirow{5}{*}{$\begin{array}{l}\text { Seča, } \\
\text { Slovenia }\end{array}$} & $\operatorname{Pg} 43$ & Unknown & $45^{\circ} 30^{\prime} 4.3^{\prime \prime}$ & $13^{\circ} 35^{\prime} 47^{\prime \prime}$ \\
\hline & $\operatorname{Pg} 44$ & Unknown & $45^{\circ} 30^{\prime} 4.4^{\prime \prime}$ & $13^{\circ} 35^{\prime} 44.5^{\prime \prime}$ \\
\hline & $\operatorname{Pg} 45$ & 'Domača' ${ }^{2}$ & $45^{\circ} 30^{\prime} 4.2^{\prime \prime}$ & $13^{\circ} 35^{\prime} 44.6^{\prime \prime}$ \\
\hline & $\operatorname{Pg} 46$ & Unknown & $45^{\circ} 30^{\prime} 4.3^{\prime \prime}$ & $13^{\circ} 35^{\prime} 47.2^{\prime \prime}$ \\
\hline & $\operatorname{Pg} 47$ & 'Italijanska'² & $\mathrm{N} 45^{\circ} 30^{\prime} 4.6^{\prime \prime}$ & $\mathrm{E}^{\prime} 3^{\circ} 35^{\prime} 45.8^{\prime \prime}$ \\
\hline
\end{tabular}

${ }^{1}$ samples included in chemical and microbiological analyses, ${ }^{2}$ local name, ${ }^{3}$ variety name

ly modified protocol of Japelaghi et al. (20) that was suitable for DNA isolation from such tissues that are rich in secondary metabolites. For protein denaturation and purification of genomic DNA, instead of the chloroform/isoamyl alcohol (24:1, by volume) mixture recommended in the original protocol (20), a phenol/chloroform/isoamyl alcohol (25:24:1, by volume; Sigma-Aldrich, St. Louis, MO, USA) mixture was used. Since no amplification of the PCR products was obtained in a PCR protocol optimisation step, two additional phenol-chloroform extractions were done on the same DNA samples, followed by isopropanol precipitation step. DNA concentrations were measured using a fluorometer (Qubit ${ }^{\mathrm{TM}}$, Invitrogen, Thermo Fisher Scientific, Waltham, MA, USA).

Twelve microsatellite loci were included into the DNA genotyping procedure: ABRII-MP30, ABRII-MP42 (15), pg08, pg10, pg17, pg18 (16), Pom006, Pom013 (14), PGCT015, PGCT088, PGCT093A and PGCT111 (7). Amplification of the microsatellites was carried out in PCR reactions in a total volume of $15 \mu \mathrm{L}$, containing the supplied PCR buffer (Promega, Mannheim, Germany), $2 \mathrm{mM}$ $\mathrm{MgCl}_{2}, 0.2 \mathrm{mM}$ of each dNTP (Sigma-Aldrich), $0.2 \mu \mathrm{M}$ of each locus-specific primer (IDT-DNA, Leuven, Belgium), with one of the primers in the pair elongated for the M13 (-21) universal sequence (IDT-DNA) (21), $0.25 \mu \mathrm{M}$ M13 (-21) universal primer labelled with 6-FAM, VIC, PET or NED (Applied Biosystems, Woolston, UK), 0.375 U of Taq DNA polymerase (Promega), and $40 \mathrm{ng}$ of DNA. The amplification of the DNA was performed in a 2720 thermal cycler (Applied Biosystems, Thermo Fisher Scientific, Singapore). For the microsatellite loci ABRII-MP, pg and Pom, the cycling conditions of the two-step PCR were as follows: first step: $94{ }^{\circ} \mathrm{C}$ for $5 \mathrm{~min}$, five cycles of $45 \mathrm{~s}$ at 94 ${ }^{\circ} \mathrm{C}, 30 \mathrm{~s}$ at $57^{\circ} \mathrm{C}$, lowered by $1{ }^{\circ} \mathrm{C}$ in each cycle, and $30 \mathrm{~s}$ at $72{ }^{\circ} \mathrm{C}$; and second step: 30 cycles of $30 \mathrm{~s}$ at $94{ }^{\circ} \mathrm{C}, 30 \mathrm{~s}$ at 52 ${ }^{\circ} \mathrm{C}$, and $90 \mathrm{~s}$ at $72{ }^{\circ} \mathrm{C}$; and a 10 -minute extension step at 72 ${ }^{\circ} \mathrm{C}$. The amplification protocol for the microsatellite locus PGCT was performed according to Schuelke (21). Separation of the amplified microsatellites was performed on a 3130 Genetic Analyzer (Applied Biosystems, Hitachi High-Technologies Corporation, Tokyo, Japan), using GeneScanTM-500 LIZ ${ }^{\circledR}$ (Applied Biosystems, Woolston, UK) for the size standards, and the data were analysed using the Gene Mapper v. 4.1 software (Applied Biosystems, Thermo Fisher Scientific, Foster City, CA, USA).

\section{Genetic data analysis}

For a total of 35 pomegranate samples, the following genetic parameters were calculated from the data for the 12 microsatellite loci: the observed and expected heterozygosity, the Hardy-Weinberg equilibrium test, the effective number of alleles, the probability of identity, the frequency of null alleles per locus, and the polymorphic information content (PIC).

The genetic parameters of observed and expected heterozygosity and PIC were calculated using the CERVUS v. 3.0.7 program (22), with the IDENTITY v. 1.0 program (23) used to calculate the probabilities of identity. The frequencies of null alleles per locus were estimated using the FreeNA v. 1.2 software (24). GENEPOP v. 4.2 $(25,26)$ was used to test the genotypic frequencies for conformance to the Hardy-Weinberg equilibrium test expectations, to test the loci for linkage disequilibrium, and to estimate the significance of the genotypic differentiation between the population pairs. Probability tests for loci with less than five alleles were based on the complete enumeration method, as described by Louis and Dempster (27), while for loci with five or more alleles, the Markov chain algorithm was used $(25,28)$, with 1000 dememorisation steps, 100 batches, and 1000 iterations per batch. 
The genetic distances between these 35 pomegranate samples were calculated using Jaccard's coefficient of similarity, and the dendrogram was constructed using the unweighted pair-group method. The correlation coefficient between the similarity matrix and the cophenetic value matrix was computed to test the goodness-of-fit of the cluster analysis. All calculations were performed using the NTSYS v. 2.02 package (29).

\section{Chemical analysis}

\section{Nutritional properties}

The water content was determined according to the AOAC 950.46 method (30). The soluble solids were measured using a hand refractometer (Atago, Bellevue, WA, USA). The protein content was determined according to the method described by Hach et al. (31). The total, soluble and insoluble fibre were determined by the modified enzymatic-gravimetric method of Lee et al. (32), using Total Dietary Fiber kit (Merck, Darmstadt, Germany). The total dietary fibre was calculated as the sum of the soluble and insoluble dietary fibre.

\section{Minerals}

The element compositions of pomegranate exocarp, mesocarp and arils were analysed using energy dispersive X-ray fluorescence spectrometry. Pellets were prepared from 0.5 to $1.0 \mathrm{~g}$ of powdered samples using a pellet die and a hydraulic press (both were made in house at Jožef Stefan Institute workshop, Ljubljana, Slovenia). As the primary excitation sources, the disc radioisotope excitation sources of ${ }^{55} \mathrm{Fe}(25 \mathrm{mCi})$ and ${ }^{109} \mathrm{Cd}(20 \mathrm{mCi})$ were used (Eckert and Ziegler, Berlin, Germany). The emitted fluorescence radiation was measured using energy dispersive $\mathrm{X}$-ray spectrometer with a $\mathrm{Si}(\mathrm{Li})$ detector (Ortec EG\&G, Oak Ridge, TN, USA), a spectroscopy amplifier (model M2024; Canberra, Meriden, CT, USA), an analogue-to-digital converter (M8075; Canberra) and a PC-based multichannel analyser (S-100; Canberra). The spectrometer was equipped with a vacuum chamber. The energy resolution of the spectrometer was $175 \mathrm{eV}$ at 5.9 $\mathrm{keV}$.

The complex X-ray spectra were examined by the analysis of $\mathrm{x}$-ray spectra by iterative least square fitting (AXIL) (33) program. The evaluated uncertainty of this procedure included the statistical uncertainty of the measured intensities and the uncertainty of the mathematical fitting procedure. The overall uncertainty of the spectral measurement and analysis was in most cases less than 1 $\%$. Quantification was then performed using the Quantitative Analysis of Environmental Samples (QAES) software developed by Nečemer et al. $(33,34)$. The estimated uncertainty of the analysis was around 5 to $10 \%$. This relatively high total estimated uncertainty was mainly due to contributions of the matrix correction and the geometry calibration procedures, which included errors of tabulated fundamental parameters, and also contributions of spectrum acquisition and analysis.

\section{Fatty acid composition}

The oil was extracted from pomegranate seeds using heptane (Sigma-Aldrich, Steinheim, Germany). The fatty acid composition of the samples was determined accord- ing to European Commission (EEC) regulation no. 2568/ 91 (annexes XA and XB) (35). The instrument used was split/splitless gas chromatograph (model 6890N; Agilent Technologies, Santa Clara, CA, USA) equipped with FID detector and the SP-2560 capillary column $(100 \mathrm{~m} \times 0.25$ $\mathrm{mm} \times 0.20 \mu \mathrm{m}$; Supelco, Sigma-Aldrich, Bellefonte, PA, USA). The fatty acid methyl esters were identified with the aid of 37-component FAME Mix 47885-U (Supelco, Sigma-Aldrich) and oil samples with the International Olive Council (IOC, Madrid, Spain) proficiency schemes.

\section{Total phenolics}

The total contents of phenolic compounds of the pomegranate fruit samples were determined spectrophotometrically with UV-Visible spectrophotometer model 8453 (Hewlett Packard, Waldbronn, Germany) (36), and are expressed as mean gallic acid equivalents, with the determinations carried out in triplicate.

\section{Assignation and quantification of phenolic compounds}

The phenolic compounds (epicatechin, catechin and gallic acid (all from Sigma-Aldrich, Steinheim, Germany), delphin (delphinidin-3,5-di-O-glucoside) and cyanin (cyanidin-3,5-di-O-glucoside; both Extrasynthese, Genay, France) and pelargonin (pelargonidin-3,5-di-O-glucoside; Sigma-Aldrich) standards were used for determining their respective multiple reaction monitoring (MRMs) using an ultra-high performance liquid chromatography system (UHPLC, model 1260 Infinity; Agilent Technologies, Santa Clara, CA, USA), interfaced with a triple-quadrupole mass spectrometer (Triple Quad 6420 LC/MS; Agilent Technologies) equipped with a binary gradient pump (model G1312B), a thermostated column compartment (model G1316A), an automatic liquid sampler (model G1329B), a HiP degasser (model G4225A), a thermostat (model G1330B), a diode array detection system (model G4212B) and a Poroshell 120 column (EC-C18; $2.7 \mu \mathrm{m} ; 3.0$ $\mathrm{mm} \times 50 \mathrm{~mm}$; Agilent Technologies). The following elution gradient deliberately modified from Luján et al. (37) was used: water/formic acid (99.5:0.5, by volume) (A) and acetonitrile/methanol (50:50, by volume) (B) with initial composition of $96 \% \mathrm{~A}$ and flow of $0.34 \mathrm{~mL} / \mathrm{min}, 0-3.96 \mathrm{~min} 50$ $\% \mathrm{~A}, 3.96-4.45 \mathrm{~min} 40 \% \mathrm{~A}, 4.45-5.94 \mathrm{~min} 0 \% \mathrm{~A}$, and $5.94-$ $7.12 \mathrm{~min} 0 \% \mathrm{~A}$. The standard phenolic compounds were dissolved in methanol and infused to optimise the acquisition parameters. The following optimised conditions were used: fragmentor voltages 80-220 V, collision energy range $15-45 \mathrm{eV}$, capillary voltage $4.0 \mathrm{kV}$, cell acceleration voltage $7 \mathrm{~V}$, and sheath gas temperature $300^{\circ} \mathrm{C}$. All of the samples were measured in duplicate. The limit of detection (LOD) was $0.01 \mathrm{mg}$ per $100 \mathrm{~g}$ of sample for epicatechin and catechin, and $0.002 \mathrm{mg}$ per $100 \mathrm{~g}$ of sample for gallic acid, delphin, cyanin and pelargonin. The levels of epicatechin, catechin, delphin, cyanin and pelargonin were calculated on the basis of the constructed calibration curves with the aid of determined MRMs, using their respective chlorides.

\section{Antioxidant activity}

The antioxidant activities of the water and ethanol extracts of the pomegranate exocarp, mesocarp and aril juice were determined spectrophotometrically using the 
2,2-diphenyl-1-picryl-hydrazyl $\left(\mathrm{DPPH}^{\circ}\right)$ reagent (Sigma-Aldrich, St. Louis, MO, USA) (38). Triplicate analyses were performed for each extract, and the procedure was previously described in detail (38).

\section{Microbiological analysis}

Antibacterial activity

The antibacterial activities of the ethanol and water extracts of the pomegranate mesocarp and exocarp were tested against a panel of pathogenic microorganisms, including Gram-positive Staphylococcus aureus (ATCC 25923) and Listeria monocytogenes (ZMJ58a), and Gram-negative Escherichia coli (ŽMJ370) and Pseudomonas aeruginosa (ŽMJ87) (all clinical isolates). The cultivation/assay media were Mueller-Hinton broth or Mueller-Hinton agar (Oxoid, Hampshire, UK). The minimum inhibitory concentrations (MICs) of the extracts were determined using the broth microdilution method, as previously described (39). To indicate respiratory activity, the presence of colour was determined after the addition of 2-p-iodophenyl-3- $p$-nitrophenyl-5-phenyltetrazolium chloride (Sigma-Aldrich) (39). All of the MIC measurements were carried out in duplicate.

\section{Antifungal activity}

The antifungal activities of the ethanol extracts of the pomegranate mesocarp and exocarp were tested against eight fungi: Saprochaete clavata (EXE 5631), Candida albicans (EXE 9382), Candida parapsilosis (EXE 9370), Aureobasidium pullulans (EXE 3105), Aspergillus fumigatus (EXE 8280), Fusarium dimerum (EXE 9214), Exophiala dermatitidis (EXE 5586) and Rhodotorula mucilaginosa (EXE 9762). These tests were carried out according to the reference methods for broth dilution antifungal susceptibility testing of yeast (M27-A3) (40) and filamentous fungi (M38-A2) (41). All of the measurements of the MICs were carried out in duplicate.

\section{Statistical analysis}

All of the chemical data were analysed using the Stata $13 \mathrm{SE}$ v. 1.0 software (42). The normality of the variable distributions was determined using Shapiro-Wilk tests. Where the data were not normally distributed, Spearman's rank correlations were used for bivariate comparisons. Where logarithmic transformations of the variables conformed to the requirements for a normal distribution, Pearson's correlations were used. Wilcoxon-Mann-Whitney tests were applied for comparisons of two different groups. The level of statistical significance was set to $\mathrm{p}<0.05$.

\section{Results and Discussion}

It is well known that the chemical composition of fruit is influenced by both genetic and environmental (e.g. climatological and edaphological) factors. Therefore, the aim of the present study was to determine the genetic variability of the pomegranate germplasm in Istria, and to characterise the plants of different genotypes in relation to their antimicrobial and nutritional properties. The genotypes with the best nutritional properties will be planted in collection orchards for further characterisation while maintaining the same ecological factors.

\section{Genetic characteristics of pomegranate}

The microsatellite primers for the pomegranate DNA genotyping and diversity study were chosen on the basis of previously reported genetic characteristics of loci. The main criteria for locus selection were: the number of amplified alleles per locus, the observed heterozygosity, and the polymorphic information content. The calculated genetic parameters over 12 loci are presented in Table 2. All 12 of these microsatellite markers were polymorphic, which defined a total of 41 alleles in the group of 35

Table 2. Diversity parameters estimated for the microsatellite loci of the pomegranate samples used in this study

\begin{tabular}{|c|c|c|c|c|c|c|c|c|}
\hline \multirow[t]{2}{*}{ Locus } & \multicolumn{2}{|c|}{ Alleles } & \multicolumn{2}{|c|}{ Heterozygosity } & \multirow[t]{2}{*}{ PIC } & \multirow{2}{*}{$\begin{array}{l}\text { Null allele } \\
\text { estimated } \\
\text { frequency }\end{array}$} & \multirow[t]{2}{*}{ p-value } & \multirow{2}{*}{$\begin{array}{l}\text { Probability } \\
\text { of identity }\end{array}$} \\
\hline & $\begin{array}{l}\text { Number } \\
\text { detected }\end{array}$ & $\begin{array}{l}\text { Effective } \\
\text { number }\end{array}$ & Observed & Expected & & & & \\
\hline ABRII-MP30 & 2 & 1.059 & 0.000 & 0.056 & 0.054 & 0.11488 & 0.0145 & 0.896683 \\
\hline ABRII-MP42 & 2 & 1.029 & 0.029 & 0.029 & 0.028 & 0.00007 & n.d. & 0.945656 \\
\hline $\operatorname{pg} 17$ & 2 & 1.724 & 0.314 & 0.426 & 0.332 & 0.08113 & 0.2196 & 0.601000 \\
\hline pg18 & 4 & 2.110 & 0.543 & 0.534 & 0.474 & 0.01947 & 0.2015 & 0.379825 \\
\hline Pom006 & 5 & 1.583 & 0.229 & 0.373 & 0.350 & 0.12516 & 0.0093 & 0.453269 \\
\hline Pom013 & 6 & 1.744 & 0.400 & 0.433 & 0.402 & 0.04303 & 0.6673 & 0.401221 \\
\hline pg8 & 2 & 1.717 & 0.281 & 0.424 & 0.330 & 0.10424 & 0.0857 & 0.600764 \\
\hline pg10 & 2 & 1.385 & 0.333 & 0.282 & 0.239 & 0.00000 & 0.5588 & 0.637346 \\
\hline PGCT015 & 3 & 2.127 & 0.618 & 0.538 & 0.472 & 0.00000 & 0.1236 & 0.395991 \\
\hline PGCT088 & 5 & 3.153 & 0.800 & 0.693 & 0.632 & 0.00000 & 0.3542 & 0.254454 \\
\hline PGCT093A & 3 & 2.470 & 0.412 & 0.604 & 0.509 & 0.11355 & 0.0043 & 0.421654 \\
\hline PGCT111 & 5 & 2.956 & 0.724 & 0.673 & 0.621 & 0.00812 & 0.0783 & 0.236525 \\
\hline Cumulative & 41 & n.c. & n.c. & n.c. & n.c. & n.c. & n.c. & $1.35 \cdot 10^{-4}$ \\
\hline
\end{tabular}

PIC=polymorphic information content, $\mathrm{p}$-value=according to the Hardy-Weinberg equilibrium test, n.d.=not determined, n.c. $=$ not calculated 
pomegranate samples. The number of alleles for each locus varied from 2 (loci ABRII-MP30, ABRII-MP42, pg17, pg8 and pg10) to 6 (locus Pom013), with a mean of 3.41 alleles and a mean of 1.92 effective alleles. Seven unique alleles were found, which were characteristic of five of the pomegranate samples: 'Pg30 wild-type' (allele 172-ABRII-MP30), 'Unknown Pg28' (alleles 196-ABRII-MP42, 145-Pom006 and 164-Pom013), 'Modraš wild-type' (allele 183-pg18), 'Medun' (allele 174-Pom013), and 'Irački ljutunac' (allele 134-PGCT088). The expected heterozygosity varied between 0.029 (ABRII-MP42) and 0.693 (PGCT088), with a mean of 0.422 . The highest observed heterozygosity $(0.800)$ was at locus PGCT088, and the lowest (0.000) at locus ABRII-MP30, where no heterozygotes were found. The PIC values ranged from 0.028 (ABRII-MP42) to 0.632 (PGCT088). Out of 12 loci, only three markers (PGCT088, PGCT093A and PGCT111) were classified among the informative loci (PIC>0.5) (43). The probability of identical genotypes varied among the loci from approx. 0.236 (PGCT111) to 0.945 (ABRII-MP42), and the common probability of identity calculated for all the loci was $1.35 \cdot 10^{-4}$. Most of the used loci (i.e. except loci PGCT088 and PGCT111) showed high probability of identity, and were thus less appropriate for discrimination of accessions. Nevertheless, the combination of the used loci allowed discrimination of these pomegranate accessions into 26 different genotype profiles. Identical DNA profiles were observed in eight cases. The results suggest that 'Rumenjaš slatki' and 'Glavaš', and also 'Barski sladun' and 'Barski žuto-narančaste kore', are synonyms. In the case of the identical DNA profiles of 'Valenciana' and 'Unknown Pg44', the identity Pg44 accession from Slovenian Istria was resolved and confirmed as the variety 'Valenciana'.

Interestingly, the values of the genetic parameters calculated in this study were not very similar to those from the previous studies of Hasnaoui et al. (14), Pirseyedi et al. (15) and Ebrahimi et al. (16). The main differences were in the observed and expected heterozygosities and the PIC values, which indicated that the characteristics of the loci were strongly influenced by the diversity and origin of the samples included in the analysis. These previous studies focused on the diversity of accessions from Tunisia $(14,16)$ and Iran $(15)$. However, similar genetic parameters to the present study were reported by Soriano et al. (7) for the PGCT primer set. Their study included 11 accessions from five distinct countries, and the number of alleles and calculated PIC values of four primers were similar (PGCT015, PGCT088, PGCT093A and PGCT111). These results suggest the need for careful selection of microsatellite primers for diversity studies of pomegranate, and the existence of very specific germplasm around the Mediterranean basin.

Deviation from the Hardy-Weinberg equilibrium was found at three loci (ABRII-MP30, Pom006 and PGCT093A). At locus ABRII-MP30, no heterozygotes were found, while locus Pom006 had the excess of one class of homozygotes, and at locus PGCT093A, of two classes of homozygotes.

Jaccard's similarity coefficient was used for the calculation of the genetic distances among pairwise combinations in the set of 35 pomegranate accessions. The dendrogram shown in Fig. 1 was constructed from the genetic similarity data, and the clusters were tested for associations. The cophenetic correlation coefficient was 0.844 , which indicated a good fit of the original data to the clustering.

The accessions were clustered into three main groups. The first cluster consisted of eight local accessions of unknown identity plus the varieties 'Rumenjaš slatki', 'Glavaš', 'Slatki rani', 'Dente di Cavallo' and 'Nar'. The second cluster comprised varieties 'Medun', 'Irački ljutunac', 'Barski sladun', 'Barski', 'Domača' and 'Wonderful'. The third cluster included the Spanish varieties 'Valenciana' and 'Mollar de Elche', as well as three local accessions and the wild pomegranate Pg21. The 'wild' accession that was sampled in the natural habitat near Rabac (Croatia) showed the lowest affinity to all of the other samples. Some of the varieties included in the molecular analysis had their origins in the Adriatic region. 'Glavaš' is believed to be a Herzegovinian autochthonous variety, whereas 'Barski sladun' is from Montenegro, and both of these varieties are reported to be commercially interesting, due to their high quality (44). Based on the clustering of the samples into the related groups, no connections between the samples according to geographical origin can be defined.

Based on the polymorphic information and their other diversity characteristics, loci pg18, Pom013, PGCT015, PGCT088 and PGCT111 demonstrated suitability and usefulness for Istrian (or in the wider context of the Adriatic region) pomegranate germplasm characterisation and identification. Other loci were less suitable due to low detected numbers of alleles, high values of probability of identity and deviation from the Hardy-Weinberg equilibrium.

Nevertheless, the set of molecular markers used in the present study allowed the first insight into the extent of pomegranate diversity in the region, and 26 different genotypes confirmed the great diversity of the analysed samples.

\section{Chemical properties of pomegranate fruit}

The levels of total and individual phenolic compounds, soluble solids, fatty acids, the antioxidant potential and antimicrobial/antifungal characteristics were determined for eight of the pomegranate samples from Istria, which represented six different genotypes (Fig. 1). The mass fractions of protein, ash, dietary fibre and minerals in the samples from exocarp, mesocarp and arils were determined in a single sample, Pg9 (Table 3), with this selection based on the morphological characteristics of the fruit (data not shown).

The protein level on wet mass basis in the arils from sample Pg9 (1.56 g/100 g) was much higher than that of the Turkish 'Hicaz' variety (0.3 g/100 g) (45). However, this was comparable with the level in the arils of the 'Wonderful' variety (1.7 g/100 g) (46), which is the most widely planted commercial variety in California, USA (8). The mass fraction of total lipids on wet mass basis in seeds from the Istrian accessions $(2.8 \mathrm{~g} / 100 \mathrm{~g})$ was much higher than in the arils from the 'Wonderful' variety (1.7 $\mathrm{g} / 100 \mathrm{~g})(46)$. The content of total dietary fibre on wet mass basis in the arils ( $3.3 \mathrm{~g} / 100 \mathrm{~g})$ was comparable with 


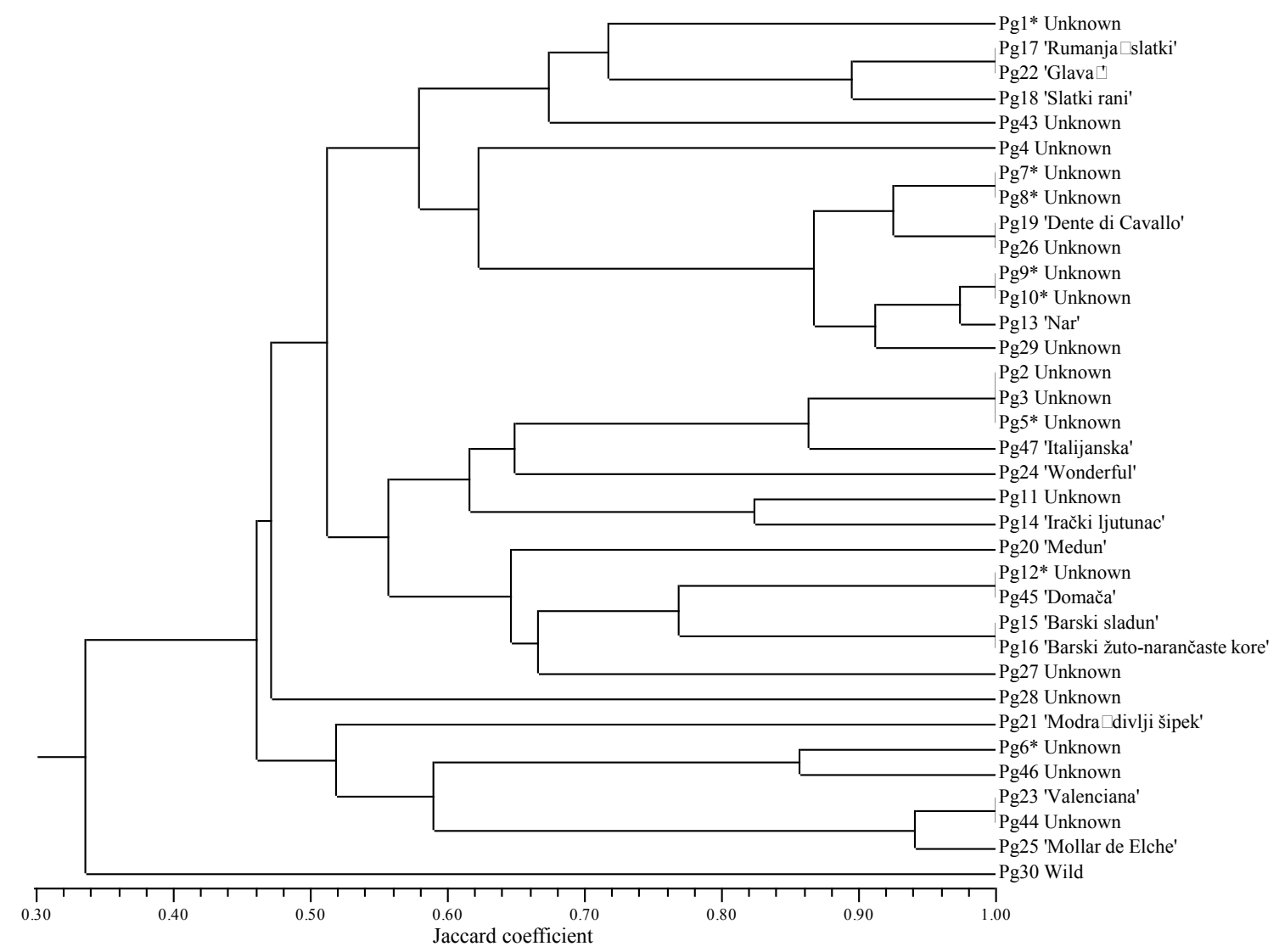

Fig. 1. Dendrogram constructed according to the unweighted pair-group method on the basis of the microsatellite data and the calculated Jaccard's similarity coefficients among the 35 pomegranate genotypes, *genotypes included in the chemical and microbiological analyses

that of the 'Wonderful' variety (4 g/100 g) (46). These data indicate that in addition to the geographical position, the genotype has an impact on the biosynthesis pathways of the protein and total lipid contents. However, these data remain to be confirmed through further investigations.

The pomegranate fruit is a good source of minerals (Table 3), especially potassium, which accounts for about $60 \%$ of all of the minerals defined here. The potassium on wet mass basis in the arils $(194 \mathrm{mg} / 100 \mathrm{~g}$, i.e. $972 \mathrm{mg} / 100 \mathrm{~g}$ dry mass) is comparable to that in the 'Wonderful' variety (236 mg/100 g) (46). The highest potassium levels were in the exocarp samples $(336 \mathrm{mg} / 100 \mathrm{~g}$ wet mass, i.e. 1460 $\mathrm{mg} / 100 \mathrm{~g}$ dry mass). In comparison with the calcium levels on wet mass basis in the exocarp of other varieties that were reported by Fawole and Opara (47) such as 'Arakta' (16 mg/100 g), 'Bhawa' (48 mg/100 g), 'Ganesh' (31 mg/100 g), 'Herskawitz' (52 mg/100 g), 'Mollar de Elche' (29 mg/100 g), 'Rubi' (61 mg/100 g) and 'Wonderful' (49 mg/100 g), the level of calcium determined in the pomegranate exocarp from Istria is the highest $(133 \mathrm{mg} / 100 \mathrm{~g}$ wet mass, i.e. $578 \mathrm{mg} / 100 \mathrm{~g}$ dry mass). One of the reasons for these high levels of calcium might be due to the flysch bedrock, as compositional differences in bedrock can be reflected in plant elemental composition (48). Moreover, the iron content determined in the arils from Istria $(0.87 \mathrm{mg} / 100 \mathrm{~g}$ wet mass, i.e. $4.4 \mathrm{mg} / 100 \mathrm{~g}$ dry mass) was also higher than the levels reported in the literature $(0.30 \mathrm{mg}$ (39) and 0.56 $\mathrm{mg} / 100 \mathrm{~g}(45))$.
The mineral content of fruit depends on genetic factors and pedoclimatic conditions. The pomegranate plants from which the fruits were harvested in the present study were growing wild, with no agricultural practices applied. We hypothesise that the main reason for the differences observed between the varieties will lie in the different pedoclimatic conditions. However, due to the relatively small sample size, further investigations are necessary to confirm these observations and to define the reasons for the elevated levels of calcium and iron in the pomegranate samples from Istria.

In the fatty acid composition of the pomegranate seeds the unsaturated fatty acids (95\%) prevailed (data not shown). Conjugated linolenic acid, which is a collective term for the positional and geometric isomers of octadecatrienoic acid (C18:3), amounted to $78.4 \%$ of all of the fatty acids determined in the pomegranate seed oil. These results are in agreement with the literature (49-51). According to Sassano et al. (49), considering all of the geometric isomers of the determined octadecatrienoic acid, punicic acid is by far the most abundant fatty acid in pomegranate seed oil, as it can amount to $72 \%$ of all of the determined fatty acids.

The total content of phenolic compounds and the antioxidant potential of these different samples of pomegranate grown in Istria are shown in Fig. 2. Here, the total content of phenolic compounds was the lowest in the aril juice samples compared to the exocarp and mesocarp, in 
Table 3. Analysis of the exocarp, mesocarp and aril of sample Pg9 (see Table 1)

\begin{tabular}{lccc}
\hline Component & \multicolumn{3}{c}{$w /(\mathrm{g} / 100 \mathrm{~g})^{*}$} \\
\cline { 2 - 4 } & Exocarp & Mesocarp & Aril \\
\hline Protein & $0.98 \pm 0.01$ & $0.98 \pm 0.01$ & $1.56 \pm 0.09$ \\
Total lipid & $<\mathrm{LOD}$ & $<\mathrm{LOD}$ & $2.8 \pm 0.1$ \\
Ash & $0.96 \pm 0.01$ & $0.79 \pm 0.01$ & $1.47 \pm 0.01$ \\
Total dietary fibre & $7.4 \pm 0.3$ & $4.7 \pm 0.1$ & $3.3 \pm 0.2$ \\
Insoluble dietary fibre & $5.4 \pm 0.3$ & $3.1 \pm 0.1$ & $3.0 \pm 0.2$ \\
Soluble fibre & $1.97 \pm 0.12$ & $1.57 \pm 0.11$ & $0.29 \pm 0.08$ \\
\hline & \multicolumn{3}{c}{$w /(\mathrm{mg} / 100 \mathrm{~g})^{* *}$} \\
\hline $\mathrm{Si}$ & $<\mathrm{LOD}$ & $<\mathrm{LOD}$ & $82 \pm 12$ \\
$\mathrm{P}$ & $111 \pm 10$ & $68 \pm 7$ & $246 \pm 29$ \\
$\mathrm{~S}$ & $36.5 \pm 4.1$ & $7.10 \pm 0.00$ & $95 \pm 11$ \\
$\mathrm{Cl}$ & $588 \pm 36$ & $460 \pm 28$ & $133 \pm 15$ \\
$\mathrm{~K}$ & $1460 \pm 89$ & $1140 \pm 69$ & $972 \pm 109$ \\
& $(336 \pm 20)^{*}$ & n.c. & $(194 \pm 22)^{*}$ \\
$\mathrm{Ca}$ & $578 \pm 35$ & $108.0 \pm 6.7$ & $34.7 \pm 3.9$ \\
& $(133 \pm 8)^{*}$ & n.c. & n.c. \\
$\mathrm{Mn}$ & $2.16 \pm 0.00$ & $2.64 \pm 0.00$ & $1.0 \pm 0.3$ \\
$\mathrm{Fe}$ & $7.4 \pm 1.0$ & $7.5 \pm 1.1$ & $4.4 \pm 0.4$ \\
& n.c. & n.c. & $(0.87 \pm 0.09)^{*}$ \\
$\mathrm{Ni}$ & $0.9 \pm 0.3$ & $1.3 \pm 0.4$ & $0.38 \pm 0.00$ \\
$\mathrm{Cu}$ & $1.2 \pm 0.2$ & $1.4 \pm 0.3$ & $0.80 \pm 0.09$ \\
$\mathrm{Zn}$ & $0.9 \pm 0.2$ & $2.0 \pm 0.3$ & $1.3 \pm 0.1$ \\
$\mathrm{Se}$ & $0.27 \pm 0.00$ & $0.50 \pm 0.00$ & $0.08 \pm 0.00$ \\
$\mathrm{Bb}$ & $0.9 \pm 0.2$ & $0.76 \pm 0.00$ & $0.06 \pm 0.03$ \\
$\mathrm{Sb}$ & $1.7 \pm 0.2$ & $0.6 \pm 0.2$ & $0.21 \pm 0.03$ \\
$\mathrm{Mo}$ & $1.2 \pm 0.2$ & $1.9 \pm 0.4$ & $0.52 \pm 0.07$ \\
$\mathrm{Br}$ & $1.2 \pm 0.1$ & $0.5 \pm 0.1$ & $0.05 \pm 0.00$ \\
& $0.16 \pm 0.00$ & $0.22 \pm 0.00$ & $0.04 \pm 0.00$ \\
\hline
\end{tabular}

Data are mean value \pm standard deviation, *expressed on wet mass basis, ${ }^{* *}$ expressed on dry mass basis, n.c. $=$ not calculated, LOD=limit of detection

both the ethanol and water extracts. The differences in the contents of total phenolic compounds in the extracts of pomegranate exocarp and mesocarp were not statistically significant.

The mass fractions of phenolic compounds (expressed in gallic acid equivalents) in the pomegranate exocarp and mesocarp were on average significantly higher $(\mathrm{p}<0.005)$ in the ethanol extracts ( 23 and $16 \mathrm{mg} / \mathrm{g}$, respectively) than in the water extracts ( 7.9 and $6.7 \mathrm{mg} / \mathrm{g}$, respectively). This is due to the prevalence of phenolic compounds that are more soluble in polar organic solvents than in an aqueous medium. However, these differences were not seen in the ethanol and water extracts of the aril juice, which is due to the ethanol extraction of the water-based medium of the juice.

It is worth mentioning that the mass fractions of the total phenolic compounds determined in the ethanol extract of the exocarp of sample Pg1 in gallic acid equiva-
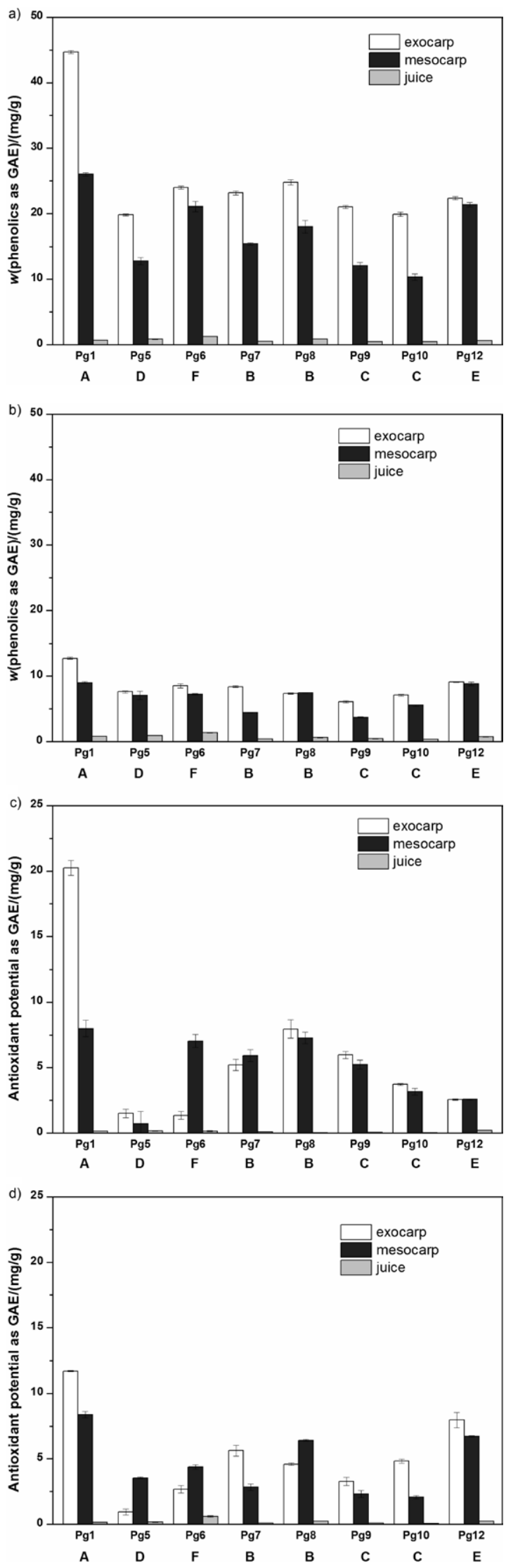

Fig. 2. Total content of: $a$ and b) phenolic compounds, and $c$ and d) antioxidant potential of: $a$ and c) ethanol, and b and d) water extracts of the eight pomegranate samples (Table 1) from Istria. A, B, C, D, E, F=different genotypes (Fig. 1) 
lents $((44.6 \pm 0.5) \mathrm{mg} / \mathrm{g})$ were particularly high in comparison with the other samples (Fig. 2). This difference might not only be due to the different genotype, but also to different geological and pedological factors. It could also be contributed to different local weather conditions, which might have had an important influence on the mass fractions of phenolic compounds. This difference was not so evident in the samples that underwent the water extraction (Fig. 2).

Different phenolic compounds have different antioxidant, antibacterial and antifungal activities. Therefore, not only were the total contents of the phenolic compounds determined, but also the levels of some of the important individual phenolic compounds that might contribute to the antioxidant, antibacterial and antifungal activities of these ethanol and water extracts. Indeed, exploitation of natural antioxidants, and especially those of plant origin, has greatly increased recently due to the restrictions of the use of synthetic antioxidants that are potentially cancerogenic $(52,53)$.

The levels of epicatechin, catechin, gallic acid, delphinidin-3,5-di-O-glucoside, cyanidin-3,5-di-O-glucoside and pelargonidin 3,5-di-O-glucoside were determined in the ethanol and water pomegranate extracts (Table 4) with HPLC-MS/MS. As shown in the table, the levels of epicatechin were the highest in the exocarp, the lowest in the aril juice, and intermediate in the mesocarp in both water and ethanol extracts. The levels of catechin were also the highest in the exocarp, although it was not detected in the aril juice samples. Moreover, the levels of gallic acid were the highest in the exocarp, followed by the mesocarp and aril juice. In most of the samples, the levels of pelargonidin-3,5-di-O-glucoside in the exocarp were higher than in the aril juice. On the other hand, the levels of delphinidin-3,5-di-O-glucoside and cyanidin-3,5-di-O-glucoside in the aril juice were in most cases higher than in the exocarp samples (Table 4).

From the data given in Table 4, it is evident that the levels of the phenolic compounds were higher in the ethanol extracts than in the water extracts, with the exception of gallic acid. This is in agreement with the data found in this study for the total content of phenolic compounds and the antioxidant potential. Furthermore, among these phenolic compounds, epicatechin generally showed the highest content in both extracts and its levels correlated with those of the total content of phenolic compounds $(\mathrm{R}=0.8, \mathrm{p}<0.05)$. However, there was no correlation between the epicatechin levels and the determined antioxidant potentials. Indeed, the mass fractions of some other specific phenolic compounds that are only found in pomegranate fruit should also be determined, such as punicalin, pedunculagin, and punicalagin, to improve the assessment of the characteristics of the pomegranate from this area.

As for the total content of phenolic compounds in the ethanol extracts of the aril juice, the antioxidant potential expressed in gallic acid equivalents was the lowest in the ethanol aril juice (mean value $0.157 \mathrm{mg} / \mathrm{g}$, minimum 0.048 and maximum $0.576 \mathrm{mg} / \mathrm{g}$ ) compared to the exocarp (mean value $4.72 \mathrm{mg} / \mathrm{g}$, minimum 1.10 and maximum
$20.5 \mathrm{mg} / \mathrm{g}$ ) and mesocarp (mean value $4.82 \mathrm{mg} / \mathrm{g}$, minimum 0.560 and maximum $8.43 \mathrm{mg} / \mathrm{g}$ ), with these differences showing statistical significance $(\mathrm{p}<0.005)$ (Fig. 2). However, the differences in the antioxidant potential of the exocarp and mesocarp extracts were not statistically significant. The antioxidant potential correlated with the total phenolic content $\left(\mathrm{R}_{\mathrm{s}}=0.8, \mathrm{p}<0.005\right)$, although this correlation was not very strong. The discrepancies between the total phenolic content and the antioxidant potential were probably related to the method used for determination of total phenolic compounds, as it is susceptible to sugars, and to the different antioxidant potentials of the individual phenolic compounds. These data for the aril juice antioxidant potential are in the same range that has been reported for the pomegranate varieties 'Arakta', 'Bhagwa', and 'Ruby' (47).

\section{Antibacterial and antifungal activities}

Antibacterial and antifungal activity tests were performed with the ethanol and water extracts of exocarp and mesocarp from the different genotypes (Fig. 1) of pomegranate grown in Istria. These were carried out against Escherichia coli, Listeria monocytogenes, Pseudomonas aeruginosa, Staphylococcus aureus, Saprochaete clavata, Candida albicans, C. parapsilosis, Aspergillus pullulans, A. fumigatus, Fusarium dimerum, Exophiala dermatitidis and Rhodotorula mucilaginosa.

As shown by the MICs in Table 5, the ethanol extracts generally showed higher antibacterial and antifungal activities and were active against more of these species than the water extracts. The positive results of antimicrobial activities against E. coli, L. monocytogenes, P. auroginosa, $S$. aureus, $C$. albicans and $A$. fumigatus are in accordance with the literature (54-56). The ethanol extracts of the exocarp and mesocarp showed the lowest MICs against C. albicans, C. parapsilosis, R. mucilaginosa, E. dermatitidis and $S$. aureus. The ethanol extracts of the exocarp did not affect the growth of $P$. aeruginosa, S. clavata and F. dimerum, while those of the mesocarp did not have any effects on $S$. clavata and F. dimerum. The highest antimicrobial activities of the exocarp and mesocarp water extracts were against $S$. aureus, followed by E. coli. According to these data, the water extracts have no antifungal properties (Table 5). Comparing the total contents of phenolic compounds and the antioxidant potentials, differences between the pomegranate samples were not noted, with the exception of sample Pg1 (genotype A), which not only had the highest total phenolic content and antioxidant potential, but also showed the best antibacterial and antifungal activities.

\section{Conclusions}

Genetic analysis with microsatellite markers revealed great diversity of pomegranate in Istria. Among the 35 samples, 11 had local denomination, four samples represented varieties known on the European level or wider, and the remaining 12 genotypes were of unknown identity. These results have confirmed the uncontrolled introduction of varieties, and the lack of past investigations supports the belief that there is an underutilisation of this 
Table 4. Phenolic compounds in the ethanol and water extracts obtained from exocarp, mesocarp, and aril juice of the different unknown varieties

\begin{tabular}{|c|c|c|c|c|c|c|c|c|}
\hline \multirow{2}{*}{ 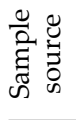 } & \multirow[t]{2}{*}{ Code } & \multirow{2}{*}{$\begin{array}{l}\text { Geno- } \\
\text { type }\end{array}$} & \multicolumn{6}{|c|}{$w /(\mathrm{mg} / 100 \mathrm{~g})^{*}$} \\
\hline & & & Epicatechin & Catechin & Gallic acid & $\begin{array}{l}\text { Delphinidin-3,5- } \\
\text {-di-O-glucoside }\end{array}$ & $\begin{array}{l}\text { Cyanidin-3,5- } \\
\text {-di-O-glucoside }\end{array}$ & $\begin{array}{l}\text { Pelargonidin-3,5- } \\
\text {-di-O-glucoside }\end{array}$ \\
\hline & & & & & Ethanol extra & & & \\
\hline \multirow{8}{*}{ 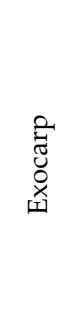 } & Pg1 & A & $6.2 \pm 0.4$ & $2.21 \pm 0.09$ & $0.78 \pm 0.02$ & $0.119 \pm 0.000$ & $0.283 \pm 0.001$ & $0.103 \pm 0.002$ \\
\hline & Pg5 & $\mathrm{D}$ & $10.4 \pm 0.4$ & $4.2 \pm 0.3$ & $0.68 \pm 0.05$ & $0.174 \pm 0.001$ & $1.87 \pm 0.06$ & $1.88 \pm 0.01$ \\
\hline & $\operatorname{Pg} 6$ & $\mathrm{~F}$ & $11.8 \pm 0.4$ & $4.7 \pm 0.3$ & $0.487 \pm 0.004$ & $0.283 \pm 0.005$ & $0.717 \pm 0.01$ & $0.202 \pm 0.002$ \\
\hline & Pg7 & B & $3.2 \pm 0.1$ & $1.38 \pm 0.04$ & $0.40 \pm 0.02$ & $0.128 \pm 0.001$ & $0.260 \pm 0.007$ & $0.40 \pm 0.02$ \\
\hline & Pg8 & B & $2.5 \pm 0.1$ & $1.09 \pm 0.07$ & $0.31 \pm 0.01$ & $0.187 \pm 0.009$ & $0.302 \pm 0.003$ & $0.32 \pm 0.02$ \\
\hline & Pg9 & C & $9.2 \pm 0.4$ & $3.6 \pm 0.2$ & $0.28 \pm 0.02$ & $0.044 \pm 0.002$ & $0.440 \pm 0.001$ & $0.19 \pm 0.01$ \\
\hline & Pg10 & $\mathrm{C}$ & $2.2 \pm 0.1$ & $0.85 \pm 0.03$ & $0.141 \pm 0.006$ & $0.025 \pm 0.001$ & $0.106 \pm 0.006$ & $0.144 \pm 0.003$ \\
\hline & Pg12 & E & $3.2 \pm 0.2$ & $1.3 \pm 0.1$ & $0.248 \pm 0.005$ & $0.050 \pm 0.001$ & $0.224 \pm 0.004$ & $0.070 \pm 0.004$ \\
\hline \multirow{8}{*}{ 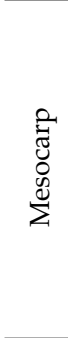 } & Pg1 & A & $0.70 \pm 0.01$ & $0.28 \pm 0.04$ & $0.233 \pm 0.001$ & n.d. & n.d. & n.d. \\
\hline & Pg5 & $\mathrm{D}$ & $0.41 \pm 0.01$ & $0.08 \pm 0.02$ & $0.127 \pm 0.001$ & n.d. & n.d. & n.d. \\
\hline & Pg6 & $\mathrm{F}$ & $0.47 \pm 0.04$ & $0.11 \pm 0.01$ & $0.051 \pm 0.002$ & n.d. & n.d. & n.d. \\
\hline & Pg7 & B & $0.18 \pm 0.01$ & $0.059 \pm 0.003$ & $0.0298 \pm 0.0001$ & n.d. & n.d. & n.d. \\
\hline & Pg8 & B & $0.168 \pm 0.008$ & $0.071 \pm 0.008$ & $0.026 \pm 0.003$ & n.d. & n.d. & n.d. \\
\hline & Pg9 & C & $0.44 \pm 0.06$ & $<\mathrm{LOD}$ & $0.078 \pm 0.004$ & n.d. & n.d. & n.d. \\
\hline & Pg10 & $\mathrm{C}$ & $0.225 \pm 0.008$ & $<\mathrm{LOD}$ & $0.0580 \pm 0.0005$ & n.d. & n.d. & n.d. \\
\hline & Pg12 & E & $0.49 \pm 0.01$ & $0.2570 \pm 0.0001$ & $0.150 \pm 0.009$ & n.d. & n.d. & n.d. \\
\hline \multirow{9}{*}{$\stackrel{\mathscr{g}}{\Xi}$} & Pg1 & A & $0.0261 \pm 0.0001$ & $<\mathrm{LOD}$ & $<\mathrm{LOD}$ & $0.37 \pm 0.01$ & $2.02 \pm 0.08$ & $0.38 \pm 0.01$ \\
\hline & Pg5 & $\mathrm{D}$ & $0.030 \pm 0.004$ & $<\mathrm{LOD}$ & $<\mathrm{LOD}$ & $1.71 \pm 0.02$ & $3.65 \pm 0.14$ & $0.81 \pm 0.02$ \\
\hline & Pg6 & $\mathrm{F}$ & $<\mathrm{LOD}$ & $<\mathrm{LOD}$ & $0.006 \pm 0.001$ & $3.01 \pm 0.02$ & $4.19 \pm 0.06$ & $0.516 \pm 0.005$ \\
\hline & Pg7 & B & $<\mathrm{LOD}$ & $<\mathrm{LOD}$ & $0.0024 \pm 0.0001$ & $0.41 \pm 0.01$ & $0.46 \pm 0.02$ & $0.064 \pm 0.002$ \\
\hline & Pg8 & B & $<\mathrm{LOD}$ & $<\mathrm{LOD}$ & $<\mathrm{LOD}$ & $0.45 \pm 0.01$ & $0.749 \pm 0.001$ & $0.1044 \pm 0.0001$ \\
\hline & Pg9 & C & $<\mathrm{LOD}$ & $<\mathrm{LOD}$ & $0.0030 \pm 0.0004$ & $0.482 \pm 0.001$ & $0.286 \pm 0.003$ & $0.030 \pm 0.001$ \\
\hline & Pg10 & $\mathrm{C}$ & $<\mathrm{LOD}$ & $<\mathrm{LOD}$ & $<\mathrm{LOD}$ & $0.99 \pm 0.03$ & $0.56 \pm 0.01$ & $0.060 \pm 0.002$ \\
\hline & $\operatorname{Pg} 12$ & E & $<\mathrm{LOD}$ & $<\mathrm{LOD}$ & $<\mathrm{LOD}$ & $0.241 \pm 0.003$ & $0.408 \pm 0.004$ & $0.077 \pm 0.003$ \\
\hline & \multicolumn{8}{|c|}{ Water extracts } \\
\hline \multirow{8}{*}{ 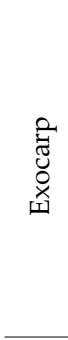 } & Pg1 & A & $0.195 \pm 0.004$ & $0.41 \pm 0.02$ & $0.552 \pm 0.007$ & $0.0532 \pm 0.0009$ & $0.0350 \pm 0.0003$ & $0.033 \pm 0.005$ \\
\hline & Pg5 & $\mathrm{D}$ & $0.307 \pm 0.004$ & $<\mathrm{LOD}$ & $0.851 \pm 0.009$ & $0.034 \pm 0.002$ & $0.80 \pm 0.01$ & $0.991 \pm 0.008$ \\
\hline & Pg6 & $\mathrm{F}$ & $0.316 \pm 0.003$ & $<\mathrm{LOD}$ & $0.50 \pm 0.07$ & $<\mathrm{LOD}$ & $0.244 \pm 0.005$ & $0.095 \pm 0.002$ \\
\hline & Pg7 & B & $0.143 \pm 0.006$ & $<\mathrm{LOD}$ & $0.17 \pm 0.01$ & $<\mathrm{LOD}$ & $0.043 \pm 0.002$ & $0.123 \pm 0.005$ \\
\hline & Pg8 & B & $0.118 \pm 0.006$ & $<\mathrm{LOD}$ & $0.179 \pm 0.007$ & $0.034 \pm 0.002$ & $0.082 \pm 0.004$ & $0.118 \pm 0.007$ \\
\hline & Pg9 & $\mathrm{C}$ & $0.24 \pm 0.05$ & $<\mathrm{LOD}$ & $0.112 \pm 0.005$ & $0.010 \pm 0.002$ & $0.042 \pm 0.001$ & $0.032 \pm 0.003$ \\
\hline & $\operatorname{Pg} 10$ & C & $0.16 \pm 0.03$ & $<\mathrm{LOD}$ & $0.087 \pm 0.005$ & $<\mathrm{LOD}$ & $0.0274 \pm 0.0008$ & $0.053 \pm 0.001$ \\
\hline & Pg12 & E & $0.155 \pm 0.002$ & $<\mathrm{LOD}$ & $0.59 \pm 0.03$ & $0.0122 \pm 0.0006$ & $0.047 \pm 0.003$ & $0.0212 \pm 0.0005$ \\
\hline \multirow{8}{*}{ 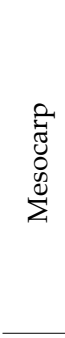 } & Pg1 & A & $<\mathrm{LOD}$ & $<\mathrm{LOD}$ & $0.146 \pm 0.002$ & n.d. & n.d. & n.d. \\
\hline & Pg5 & $\mathrm{D}$ & $0.082 \pm 0.008$ & $<\mathrm{LOD}$ & $0.72 \pm 0.01$ & n.d. & n.d. & n.d. \\
\hline & Pg6 & $\mathrm{F}$ & $0.048 \pm 0.009$ & $<\mathrm{LOD}$ & $0.10 \pm 0.01$ & n.d. & n.d. & n.d. \\
\hline & Pg7 & B & $0.035 \pm 0.005$ & $<\mathrm{LOD}$ & $0.0411 \pm 0.0004$ & n.d. & n.d. & n.d. \\
\hline & Pg8 & B & $0.022 \pm 0.003$ & $<\mathrm{LOD}$ & $0.059 \pm 0.002$ & n.d. & n.d. & n.d. \\
\hline & Pg9 & $\mathrm{C}$ & $0.0250 \pm 0.0007$ & $<\mathrm{LOD}$ & $0.099 \pm 0.002$ & n.d. & n.d. & n.d. \\
\hline & $\operatorname{Pg} 10$ & C & $0.0172 \pm 0.0001$ & $<\mathrm{LOD}$ & $0.044 \pm 0.005$ & n.d. & n.d. & n.d. \\
\hline & Pg12 & E & $0.061 \pm 0.002$ & $<\mathrm{LOD}$ & $0.109 \pm 0.009$ & n.d. & n.d. & n.d. \\
\hline \multirow{8}{*}{$\stackrel{\mathscr{U}}{\Xi}$} & Pg1 & A & $<\mathrm{LOD}$ & $<\mathrm{LOD}$ & $0.005 \pm 0.002$ & $0.0019 \pm 0.0001$ & $0.201 \pm 0.001$ & $0.0603 \pm 0.0004$ \\
\hline & Pg5 & $\mathrm{D}$ & $<\mathrm{LOD}$ & $<\mathrm{LOD}$ & $0.010 \pm 0.003$ & $0.0533 \pm 0.0002$ & $1.08 \pm 0.03$ & $0.229 \pm 0.004$ \\
\hline & Pg6 & $\mathrm{F}$ & $<\mathrm{LOD}$ & $<\mathrm{LOD}$ & $0.0018 \pm 0.0001$ & $0.243 \pm 0.006$ & $0.29 \pm 0.04$ & $0.0270 \pm 0.0001$ \\
\hline & Pg7 & B & $<\mathrm{LOD}$ & $<\mathrm{LOD}$ & $0.0042 \pm 0.0001$ & $0.000164 \pm 0.00001$ & $0.065 \pm 0.003$ & $0.0130 \pm 0.0003$ \\
\hline & Pg8 & B & $<\mathrm{LOD}$ & $<\mathrm{LOD}$ & $0.0084 \pm 0.0008$ & $0.0017 \pm 0.0002$ & $0.111 \pm 0.004$ & $0.0206 \pm 0.0001$ \\
\hline & Pg9 & C & $<\mathrm{LOD}$ & $<\mathrm{LOD}$ & $0.0036 \pm 0.0007$ & $0.098 \pm 0.001$ & $0.078 \pm 0.003$ & $0.0074 \pm 0.0001$ \\
\hline & $\operatorname{Pg} 10$ & C & $<\mathrm{LOD}$ & $<\mathrm{LOD}$ & $0.0016 \pm 0.0001$ & $0.100 \pm 0.001$ & $0.064 \pm 0.003$ & $0.00678 \pm 0.00003$ \\
\hline & Pg12 & E & $<\mathrm{LOD}$ & $<\mathrm{LOD}$ & $0.0010 \pm 0.0001$ & $0.00502 \pm 0.00007$ & $0.0181 \pm 0.0001$ & $0.0031 \pm 0.0002$ \\
\hline
\end{tabular}

Data are mean value \pm standard deviation, *expressed on wet mass basis, LOD=limit of detection, $n$. .d.=not determined 
Table 5. Antibacterial and antifungal activities (MIC) of the ethanol and water extracts of exocarp and mesocarp according to the sample and genotype (A, B, C, D, E and F) of the pomegranate grown in Istria

\begin{tabular}{|c|c|c|c|c|c|c|c|c|c|}
\hline \multirow{2}{*}{ 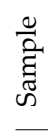 } & \multirow[t]{2}{*}{ Microorganism } & \multicolumn{8}{|c|}{$\mathrm{MIC} /(\mathrm{mg} / \mathrm{mL})$} \\
\hline & & $\begin{array}{l}\text { Pg1 } \\
\text { (A) }\end{array}$ & $\begin{array}{l}\text { Pg5 } \\
\text { (D) }\end{array}$ & $\begin{array}{l}\text { Pg6 } \\
\text { (F) }\end{array}$ & $\begin{array}{l}\text { Pg7 } \\
\text { (B) }\end{array}$ & $\begin{array}{c}\text { Pg8 } \\
\text { (B) }\end{array}$ & $\begin{array}{l}\mathrm{Pg} 9 \\
\text { (C) }\end{array}$ & $\begin{array}{c}\text { Pg10 } \\
\text { (C) }\end{array}$ & $\begin{array}{c}\text { Pg12 } \\
\text { (E) }\end{array}$ \\
\hline \multicolumn{10}{|c|}{ Ethanol extracts } \\
\hline \multirow{12}{*}{ 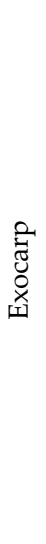 } & Escherichia coli & 1.25 & 2.5 & 2.5 & 2.5 & 2.5 & 2.5 & 2.5 & 2.5 \\
\hline & Listeria monocytogenes & 2.5 & 5 & 5 & 5 & 5 & 5 & 5 & 5 \\
\hline & Pseudomonas aeruginosa & n.d. & n.d. & n.d. & n.d. & n.d. & n.d. & n.d. & n.d. \\
\hline & Staphylococcus aureus & 0.156 & 0.312 & 0.312 & 0.312 & 0.312 & 0.312 & 0.312 & 0.312 \\
\hline & Saprochaete clavata & n.d. & n.d. & n.d. & n.d. & n.d. & n.d. & n.d. & n.d. \\
\hline & Candida albicans & 0.156 & 0.312 & 0.312 & 0.312 & 0.312 & 0.312 & 0.312 & 0.312 \\
\hline & Candida parapsilosis & 0.156 & 0.312 & 0.312 & 0.312 & 0.312 & 0.312 & 0.312 & 0.312 \\
\hline & Aureobasidium pullulans & 2.5 & 5 & 5 & 5 & 5 & 5 & 5 & 5 \\
\hline & Aspergillus fumigatus & 1.25 & 2.5 & 2.5 & 2.5 & 2.5 & 2.5 & 2.5 & 2.5 \\
\hline & Fusarium dimerum & n.d. & n.d. & n.d. & n.d. & n.d. & n.d. & n.d. & n.d. \\
\hline & Exophiala dermatitidis & 0.312 & 1.25 & 0.625 & 0.625 & 0.625 & 0.625 & 0.625 & 0.625 \\
\hline & Rhodotorula mucilaginosa & 0.156 & 0.312 & 0.312 & 0.312 & 0.312 & 0.312 & 0.312 & 0.312 \\
\hline \multirow{13}{*}{ 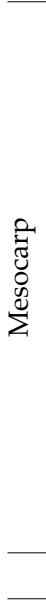 } & Escherichia coli & 2.5 & 5 & 5 & 5 & 5 & 5 & 5 & 2.5 \\
\hline & Listeria monocytogenes & 5 & 10 & 10 & 10 & 10 & 10 & 10 & 10 \\
\hline & Pseudomonas aeruginosa & 10 & 10 & 5 & 10 & 10 & 10 & 10 & 5 \\
\hline & Staphylococcus aureus & 0.312 & 1.25 & 0.625 & 0.625 & 0.625 & 1.25 & 0.625 & 0.312 \\
\hline & Saprochaete clavata & n.d. & n.d. & n.d. & n.d. & n.d. & n.d. & n.d. & n.d. \\
\hline & Candida albicans & 0.312 & 0.625 & 0.625 & 0.625 & 0.625 & 0.625 & 0.625 & 0.625 \\
\hline & Candida parapsilosis & 0.156 & 0.312 & 0.312 & 0.312 & 0.312 & 0.312 & 0.312 & 0.156 \\
\hline & Aureobasidium pullulans & 5 & 10 & 10 & 10 & 10 & 10 & 10 & 5 \\
\hline & Aspergillus fumigatus & 2.5 & 5 & 5 & 5 & 5 & 5 & 5 & 1.25 \\
\hline & Fusarium dimerum & n.d. & n.d. & n.d. & n.d. & n.d. & n.d. & n.d. & n.d. \\
\hline & Exophiala dermatitidis & 0.625 & 1.25 & 0.625 & 1.25 & 1.25 & 1.25 & 1.25 & 0.625 \\
\hline & Rhodotorula mucilaginosa & 0.156 & 0.312 & 0.312 & 0.312 & 0.312 & 0.312 & 0.312 & 0.156 \\
\hline & \multicolumn{9}{|c|}{ Water extracts } \\
\hline \multirow{4}{*}{ 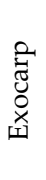 } & Escherichia coli & 2.5 & 5 & 5 & 5 & 5 & 5 & 5 & 5 \\
\hline & Listeria monocytogenes & 5 & 10 & 10 & 10 & 10 & 10 & 10 & 10 \\
\hline & Pseudomonas aeruginosa & 10 & n.d. & n.d. & n.d. & n.d. & n.d. & n.d. & n.d. \\
\hline & Staphylococcus aureus & 0.625 & 1.25 & 1.25 & 1.25 & 1.25 & 1.25 & 1.25 & 1.25 \\
\hline \multirow{4}{*}{ 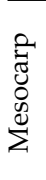 } & Escherichia coli & 2.5 & 5 & 5 & 5 & 5 & 5 & 5 & 2.5 \\
\hline & Listeria monocytogenes & 10 & n.d. & 10 & n.d. & n.d. & n.d. & n.d. & 10 \\
\hline & Pseudomonas aeruginosa & n.d. & n.d. & 10 & n.d. & n.d. & n.d. & n.d. & 10 \\
\hline & Staphylococcus aureus & 0.625 & 1.25 & 1.25 & 1.25 & 1.25 & 2.5 & 1.25 & 0.625 \\
\hline
\end{tabular}

MIC=minimum inhibitory concentration, n.d.=not determined

fruit species in the region. Genetic parameters obtained with fingerprinting analysis of a set of pomegranate genotypes revealed the five most informative microsatellites (pg18, Pom013, PGCT015, PGCT088 and PGCT111), which could be recommended as a standard set for further investigations of germplasm from the East Adriatic region.

In this study, preliminary results of mass fractions of proteins, ash, dietary fibre and minerals in arils, exocarp and mesocarp of pomegranate fruit were obtained. Elevated levels of calcium were found in pomegranate exocarp. However, more data is needed to confirm these observations. Our study confirmed that the prevailing acid in pomegranate seeds was conjugated linolenic acid. Total content of phenolic compounds was higher in ethanol extracts than in water extracts of pomegranate mesocarp and exocarp. Total mass fractions of phenolic compounds (expressed in gallic acid equivalents) and antioxidant potential were much lower in juice extracts. The total mass fractions of phenolic compounds, antioxidant potential and antimicrobial activity were higher in sample Pg1 than in other samples. Therefore, further genetic characterisation and chemical analysis of Pg1 should be performed. In regard to individual phenolic compounds, epicatechin, catechin and gallic acid were determined in water and 
ethanol extracts of all three fractions. Delphinidin-3,5-di-O-glucoside, cyanidin-3,5-di-O-glucoside and pelargonidin-3,5-di-O-glucoside were determined in ethanol and water extracts of pomegranate juice and exocarp. Our data suggest that the ethanol extracts of pomegranate exocarp and mesocarp are the most efficient against Candida albicans, Candida parapsilosis, Rhodontula mucilaginosa, Exophiala dermatitidis and Staphylococcus aureus and water extracts of pomegranate exocarp and mesocarp are most efficient against $S$. aureus, followed by Escherichia coli. The ethanol extracts have in general much higher antibacterial and antifungal activity and are active against more species than the water extracts, which corresponds with their higher content of phenolic compounds.

\section{Acknowledgements}

The project was partially financed by the EU Funds for Regional Development (SI-HR-3-2-001) and the Government Office for Development and European Cohesion Policy, Slovenia. We thank anonymous referees and the editor for valuable suggestions.

\section{References}

1. Kaczmarska E, Gawroński J, Dyduch-Siemińska M, Najda A, Marecki W, Żebrowska J. Genetic diversity and chemical characterization of selected Polish and Russian cultivars and clones of blue honeysuckle (Lonicera caerulea). Turk J Agric For. 2015;39:394-402.

https://doi.org/10.3906/tar-1404-149

2. Mlček J, Valšíková $M$, Družbíková $H$, Ryant $P$, Juríková $T$, Sochor J, Borkovcová M. The antioxidant capacity and macroelement content of several onion cultivars. Turk J Agric For. 2015;39:999-1004.

https://doi.org/10.3906/tar-1501-71

3. İpek A, Yılmaz K, Sıkıcı P, Tangu NA, Öz AT, Bayraktar M, et al. SNP discovery by GBS in olive and the construction of a high-density genetic linkage map. Biochem Genet. 2016;54: 313-25.

https://doi.org/10.1007/s10528-016-9721-5

4. Tsou C, Li L, Vijayan K. The intra-familial relationships of Pentaphylacaceae s.l. as revealed by DNA sequence analysis. Biochem Genet. 2016;54:270-82. https://doi.org/10.1007/s10528-016-9717-1

5. Integrated Taxonomic Information System (ITIS). 2015. Available from: https://www.itis.gov/servlet/SingleRpt/SingleRpt? search_topic=TSN\&search_value $=27074$.

6. Stover E, Mercure EW. The pomegranate: a new look at the fruit of paradise. HortScience. 2007;42:1088-92.

7. Soriano JM, Zuriaga E, Rubio P, Llácer G, Infante R, Badenes ML. Development and characterization of microsatellite markers in pomegranate (Punica granatum L.). Mol Breeding. 2011;27:119-28.

https://doi.org/10.1007/s11032-010-9511-4

8. Holland D, Hatib K, Bar-Ya'akov I. Pomegranate: botany, horticulture, breeding. In: Janick J, editor. Horticultural Reviews, vol. 35. Hoboken, NJ, USA: John Wiley \& Sons, Inc.; 2009. pp. 127-91. https://doi.org/10.1002/9780470593776.ch2

9. Gumienna M, Szwengiel A, Górna B. Bioactive components of pomegranate fruit and their transformation by fermentation processes. Eur Food Res Technol. 2016;242:631-40. https://doi.org/10.1007/s00217-015-2582-z

10. Viuda-Martos M, Fernández-López J, Pérez-Álvarez JA. Pomegranate and its many functional components as related to human health: a review. Compr Rev Food Sci Food Saf. 2010;9:635-54. https://doi.org/10.1111/j.1541-4337.2010.00131.x

11. Williams JT, Haq N. Global research on underutilized crops. An assessment of current activities and proposals for enhanced cooperation. Southampton, UK: International Centre for Underutilised Crops (ICUC); 2000.

12. Nafees M, Jaskani MJ, Ahmed S, Awan FS. Morpho-molecular characterization and phylogenetic relationship in pomegranate germplasm of Pakistan. Pak J Agri Sci. 2005;52:97106.

13. Curró S, Caruso M, Distefano G, Gentile A, La Malfa S. New microsatellite loci for pomegranate, Punica granatum (Lythraceae). Am J Bot. 2010;97:e58-60. https://doi.org/10.3732/ajb.1000143

14. Hasnaoui N, Buonamici A, Sebastiani F, Mars M, Trifi M, Vendramin GG. Development and characterization of SSR markers for pomegranate (Punica granatum L.) using an enriched library. Conservation Genet Resour. 2010;2:283-5. https://doi.org/10.1007/s12686-010-9191-8

15. Pirseyedi SM, Valizadehghan S, Mardi M, Ghaffari MR, Mahmoodi P, Zahravi M, et al. Isolation and characterization of novel microsatellite markers in pomegranate (Punica granatum L.). Int J Mol Sci. 2010;11:2010-6. https://doi.org/10.3390/ijms11052010

16. Ebrahimi S, Sayed-Tabatabaei BE, Sharifnabi B. Microsatellite isolation and characterization in pomegranate (Punica granatum L.). Iran J Biotechnol. 2010;8:156-63.

17. Hasnaoui N, Buonamici A, Sebastiani F, Mars M, Zhang D, Vendramin GG. Molecular genetic diversity of Punica granatum L. (pomegranate) as revealed by microsatellite DNA markers (SSR). Gene. 2012;493:105-12. https://doi.org/10.1016/j.gene.2011.11.012

18. Ogrin D. The climate in the Slovene Istria. Koper, Slovenia: Knjižnica Annales; 1995 (in Slovenian).

19. Ozgen M, Durgaç C, Serçe SM, Kaya C. Chemical and antioxidant properties of pomegranate cultivars grown in the Mediterranean region of Turkey. Food Chem. 2008;111:7036. https://doi.org/10.1016/j.foodchem.2008.04.043

20. Japelaghi RH, Haddad R, Garossi GA. Rapid and efficient isolation of high quality nucleic acids from plant tissue rich in polyphenols and polysaccharides. Mol Biotechnol. 2011; 49:129-37. https://doi.org/10.1007/s12033-011-9384-8

21. Schuelke M. An economic method for the fluorescent labelling of PCR fragments. Nat Biotechnol. 2000;18:233-4. https://doi.org/10.1038/72708

22. Kalinowski ST, Taper ML, Marshall TC. Revising how the computer program CERVUS accommodates genotyping error increases success in paternity assignment. Mol Ecol. 2007; 16:1099-106. https://doi.org/10.1111/j.1365-294X.2007.03089.x

23. Wagner HW, Sefc KM. IDENTITY v. 1.0. Vienna, Austria: Centre for Applied Genetics, University of Agricultural Sciences; 1999.

24. Chapuis MP, Estoup A. Microsatellite null alleles and estimation of population differentiation. Mol Biol Evol. 2007;24: 621-31. https://doi.org/10.1093/molbev/msl191

25. Raymond M, Rousset F. GENEPOP v. 1.2: population genetics software for exact tests and ecumenicism. J Hered. 1995; 86:248-9. https://doi.org/10.1093/oxfordjournals.jhered.a111573

26. Rousset F. GENEPOP'007: a complete reimplementation of the GENEPOP software for Windows and Linux. Mol Ecol 
Resour. 2008;8:103-6.

https://doi.org/10.1111/j.1471-8286.2007.01931.x

27. Louis EJ, Dempster ER. An exact test for Hardy-Weinberg and multiple alleles. Biometrics. 1987;43:805-11. https://doi.org/10.2307/2531534

28. Guo SW, Thompson EA. Performing the exact test of HardyWeinberg proportion for multiple alleles. Biometrics. 1992; 48:361-72.

29. Rohlf FJ. NTSYS: numerical taxonomy and multivariate analysis system, v. 2.02. Setauket, NY, USA: Applied Biostatistics Inc.; 1998.

30. AOAC Official Method 950.46. Moisture in meat. Rockville, MD, USA: AOAC International; 1997.

31. Hach CC, Bowden BK, Kopelove AB, Brayton SV. More powerful peroxide Kjeldahl digestion method. J Assoc Off Anal Chem. 1987;70:783-7.

32. Lee SC, Prosky L, Devries JW. Determination of total, soluble, and insoluble dietary fiber in foods - enzymatic gravimetric method, MES-TRIS buffer - collaborative study. J Assoc Off Anal Chem. 1992;75:395-416.

33. Nečemer M, Kump P, Ščančar J, Jaćimović R, Simčič J, Pelicon $\mathrm{P}$, et al. Application of X-ray fluorescence analytical techniques in phytoremediation and plant biology studies. Spectrochim Acta B. 2008;63:1240-7.

https://doi.org/10.1016/j.sab.2008.07.006

34. Nečemer M, Kump P, Vogel-Mikuš K. Use of X-ray fluorescence-based analytical techniques in phytoremediation. In: Golubev IA, editor. Handbook of phytoremediation. New York, NY, USA: Nova Science Publishers Inc.; 2011. pp. 33158.

35. European Commission regulation (EEC) no. 2568/91 of 11 July 1991 on the characteristics of olive oil and olive-residue oil and on the relevant methods of analysis (annexes XA and XB). Brussels, Belgium: European Commission; 1991. pp. 60-71. Available from: https://eur-lex.europa.eu/eli/reg/1991/ 2568/2015-01-01.

36. Waterman PG, Mole S. Analysis of phenolic plant metabolites. Oxford, UK: Blackwell Scientific Publications; 1994.

37. Luján RJ, Capote FP, Marinas A, Luque de Castro MD. Liquid chromatography/triple quadrupole tandem mass spectrometry with multiple reaction monitoring for optimal selection of transitions to evaluate nutraceuticals from olive tree materials. Rapid Commun Mass Spectrom. 2008;22:855-64. https://doi.org/10.1002/rcm.3423

38. Brand-Williams W, Cuvelier ME, Berset C. Use of a free-radical method to evaluate antioxidant activity. LWT - Food Sci Technol. 1995;28:25-30. https://doi.org/10.1016/S0023-6438(95)80008-5

39. Klančnik A, Piskernik S, Jeršek B, Smole Možina S. Evaluation of diffusion and dilution methods to determine the antibacterial activity of plant extracts. J Microbiol Methods. 2010; 81:121-6. https://doi.org/ 10.1016/j.mimet.2010.02.004

40. CLSI M27-A3. Reference method for broth dilution antifungal susceptibility testing of yeasts. Wayne, PA, USA: Clinical and Laboratory Standards Institute (CLSI); 2008.

41. CLSI M38-A2. Reference method for broth dilution antifungal susceptibility testing of filamentous fungi. Wayne, PA, USA: Clinical and Laboratory Standards Institute (CLSI); 2008.
42. Stata 13 SE v. 1.0 statistical software. College Station, TX, USA: StataCorp LP; 2013. Available from: https://www.stata. com.

43. Botstein D, White RL, Skolnick M, Davis RW. Construction of genetic linkage map in man using restriction fragment length polymorphisms. Am J Hum Genet 1980;32:314-31.

44. Džubur A. Pomegranate (Punica granatum L.). Mostar, Bosnia and Herzegovina: IC Štamparija; 2007 (in Bosnian).

45. TFCD. Turkish Food Composition Database. Ankara, Turkey: General Dicrectorate of Agricultural Research and Policy; 2015. Available from: https://www.turkomp.gov.tr/content/about?locale=en

46. USDA National Nutrient Database for Standard Reference Release 27. Washington DC, USA: United States Department of Agriculture (USDA); 2015. Available from: https://www. ars.usda.gov/Services/docs.htm?docid=8964

47. Fawole OA, Opara UL. Composition of trace and major minerals in different parts of pomegranate (Punica granatum) fruit cultivars. Brit Food J. 2012;114:1518-32. https://doi.org/10.1108/00070701211273009

48. Song BY, Gautam MK, Ryu JS, Lee D, Lee KS. Effects of bedrock on the chemical and $\mathrm{Sr}$ isotopic compositions of plants. Environ Earth Sci. 2015;74:829-37. https://doi.org/10.1007/s12665-015-4087-2

49. Sassano G, Sanderson P, Franx J, Groot P, van Straalen J, Bassaganya-Riera J. Analysis of pomegranate seed oil for the presence of jacaric acid. J Sci Food Agric. 2009;89:1046-52. https://doi.org/10.1002/jsfa.3552

50. Melgarejo P, Salazar DM, Amorós A, Artés F. Total lipids content and fatty acid composition of seed oils from six pomegranate cultivars. J Sci Food Agric. 1995;69:253-6. https://doi.org/10.1002/jsfa.2740690216

51. Melgarejo P, Artés F. Total lipid content and fatty acid composition of oilseed from lesser known sweet pomegranate clones. J Sci Food Agric. 2000;80:1452-4.

https://doi.org/10.1002/1097-0010(200008)80:10<1452::AIDJSFA665>3.0.CO;2-L

52. Jayaprakasha GK, Rao LJ. Phenolic constituents from the lichen Parmotrema stuppeum (Nyl.) Hale and their antioxidant activity. Z Naturforsch C. 2000;55c:1018-22. https://doi.org/10.1515/znc-2000-11-1227

53. Singh RP, Chidambara Murthy KN, Jayaprakasha GK. Studies on the antioxidant activity of pomegranate (Punica granatum) pell and seed extracts using in vitro models. J Agric Food Chem. 2002;50:81-6. https://doi.org/10.1021/jf010865b

54. Duman AD, Ozgen M, Dayisoylu KS, Erbil N, Durgac C. Antimicrobial activity of six pomegranate (Punica granatum L.) varieties and their relation to some of their pomological and phytonutrient characteristics. Molecules. 2009;14:1808-17. https://doi.org/10.3390/molecules14051808

55. Al-Zoreky NS. Antimicrobial activity of pomegranate (Punica granatum L.) fruit peels. Int J Food Microbiol. 2009;134: 244-8. https://doi.org/10.1016/j.ijfoodmicro.2009.07.002

56. Reddy MK, Gupta SK, Jacob MR, Khan SI, Ferreira D. Antioxidant, antimalarial and antimicrobial activities of tannin-rich fractions, ellagitannins and phenolic acids from Punica granatum L. Planta Med. 2007;73:461-7. https://doi.org/10.1055/s-2007-967167 